\title{
TACKLING THE MENACE OF CORONA VIRUS PANDEMIC: EXPLORING ALTERNATIVE STRATEGY OF SOCIAL RESPONSIBILITY INITIATIVE THROUGH SOCIAL STUDIES CURRICULUM
}

\author{
David Babatunde, Akınola ${ }^{i}$ \\ PhD, Department of Educational Foundations, \\ University of Abuja, P. M. B. 117, \\ Abuja, Nigeria
}

\begin{abstract}
:
This paper is titled "tackling the menace of corona virus pandemic: exploring alternative strategy of social responsibility initiative through social studies curriculum". The paper x-rayed the concept of Corona Virus Pandemic, Social Responsibility Initiative and Social Studies curriculum. The paper explained the theoretical framework, origin of Corona Virus in global perspectives, index case of Corona Virus in Nigeria and efforts to check the spread of COVID-19 in Nigeria. The article advocated for the ways of tackling the Menace of Corona Virus Pandemic by Exploring Alternative Strategy of Social Responsibility Initiative (ASSRI) through Social Studies Curriculum. The paper recommended among others that everyone must be diligent in performing his/her role in curtailing the spread of COVID- 19 pandemic by saving themselves and others.
\end{abstract}

Keywords: Corona Virus Pandemic, social responsibility initiative and social studies curriculum

\section{Introduction}

Corona Virus also known as COVID-19 is a pandemic that has shaken the low and mighty nations all over the globe. It is the combination of viruses that is dreaded by all irrespective of race, state, class, clime or religion orientations. It has introduced the new normal in all areas of human endeavour. It has sent fears down the spines of low and mighty. It is like a death sentence. It has reduced and is still reducing the world population by the number of people that have died and are still dying. Several efforts have been made the world over but the virus is still alive. Every citizen the world over has a role to play in reversing the trends of this killer virus. Therefore, this paper advocated that the menace of Corona Virus Pandemic can be tackled by exploring

i Correspondence: email david.akinola@uniabuja.edu.ng 
Alternative Strategy of Social Responsibility Initiative (ASSRI) through Social Studies curriculum.

\section{Conceptual Analysis}

\subsection{Corona Virus Pandemic}

It is also known as COVID-19. Corona Viruses comprises of a family of viruses that can cause illness such as the common cold, Severe Acute Respiratory Syndrome (SARs) and Middle East Respiratory Syndrome (MERs).

In 2019, a New Corona Virus emerged in China which caused outbreak that is presently ravaging the world. The virus is now known as the Severe Acute Respiratory Syndrome (Corona virus II or SARs-COV-2). It is one of the seven viruses. The diseases caused are known as Corona Virus Diseases of 2019 (COVID-19). World Health Organization (WHO) has declared the COVID-19 outbreak a Pandemic (MFMER 19982020, majorclinic.org)

\subsection{Social Responsibility Initiative}

Man is both a biological being and a social being; man interacts with one another to develop problem solving skills, and thinking skills to resolve the emerging issues as they live together. One of such issues is Corona Virus Pandemic. This scenario is crucial and imperative and should be tackled through Collective Social Responsibility Initiative (CSRI). Akinola (2013) opined that Social Responsibility means acting with concern, sensitivity and aware of the impact of your actions on others, particularly the disadvantaged. It connotes that every member of the society has a role to play in tackling the menace of corona virus and seek for the role of an individual in the survival of the larger society. Akinola (2013) also defined Social Responsibility Initiative (SRI) as a way of infusing systematic practices that create safe, caring and equitable life through Social Studies curriculum so that all young people succeed in school and live and help shape a safe, democratic and just society. For the nations of the world to tackle the menace of dreaded Corona Virus Pandemic, that has shaken the low and mighty nations to the very foundations, there must be harmonious relationship among the institutions through social responsibility initiatives using the instrumentality of Social Studies curriculum. According to Danladi (2008), one of the goals Social Studies curriculum is to produce effective citizens who are socially responsible.

\subsection{Social Studies Curriculum}

Social Studies curriculum can be defined as centripetal and centrifugal socio-civic experiences given to the learner in any citadel of learning. Social Studies as a curriculum offering according to Adaralegbe (1980) is a problem-solving approach discipline. Lawal and Oyeleye cited in Akinola (2014) described Social Studies as a discipline which attempts to modify or change the learners' behaviour in the direction of acceptable values and attitudes through a process of studying human beings' relationships with their 
environment and with the desire to provide solution to various complementary problems in order to ensure their survival, having being equipped with the necessary tools, such as values, attitudes, skills and knowledge. Human beings interact in their social milieu and develop the capacity as a rational being to solve the problems as they arise and develop copying strategies to live with those problems that are beyond human comprehension.

Akinola (2018) viewed Social Studies as a process of acquiring intellectual skills to live a useful life in a world that is full of opportunities and challenges. One of the current challenges of the present time is the menace of dreaded Corona Virus Pandemic which is ravaging the world unabated.

Kazi in Akinola (2018) opined that, Social Studies is an eclectic distillation of social phenomena for socio-civic living or behaviour in the society. The social phenomenon in this case is COVID 19 pandemic. Also, Akinola (2014) defines Social Studies as a process by which an individual acquires values, attitudes, skills and knowledge which will help him/her to be useful to himself / herself and the society at large as he or she interacts with others in the environment. Acquiring, imbibing and manifesting positive; values, attitudes, skills and knowledge are integral for nipping in the bud the challenge of COVID 19 pandemic.

\subsection{Theoretical Framework}

The theoretical framework relevant to this article is system theory. System theory was proposed in the 1940s. It was propounded by Ludwig von Bertalanffy (1968) and furthered by Ross Ashby (1964). The major significance of system theory is to develop unifying principles by the integration of various subsystems to achieve the desired results. It is relevant to this article in that, nations, institutions and human beings should work harmoniously to tackle the menace of dreaded COVID-19 head on. This is achievable if and only if everyone adopts Collective Social Responsibility Initiative.

\section{Origin of Corona Virus in Global Perspectives}

Corona Virus Pandemic is not the first global pandemic and may not be the last as long as the life continues on the planet earth. There are several explanations to the origin of COVID 19 pandemic one of such according to Muhammad Adnan Shereen, Suliman Khan, Abeer Kazmi, Nadia Bashir, Rabeea Siddique (2020) is that the novel coronavirus originated from the Hunan seafood market at Wuhan, China where bats, snakes, raccoon dogs, palm civets, and other animals are sold, and rapidly spread up to 109 countries. The zoonotic source of SARS-CoV-2 is not confirmed, however, sequence-based analysis suggested bats as the key reservoir. DNA recombination was found to be involved at spike glycoprotein which assorted SARS-CoV (CoVZXC21 or CoVZC45) with the RBD of another Beta $\mathrm{CoV}$, thus could be the reason for cross-species transmission and rapid infection. The virus appeared in Wuhan, China, in late 2019. The new type of coronavirus, which presents itself with symptoms such as high fever, cough and subsequent 
pneumonia, has spread rapidly and affected the whole world. The fact that it spreads like wildfire is what makes it dangerous (Janmejaya Samal, 2014). history.

In the retrospect, these are the catastrophic pandemics throughout global human

Table 1: Diagrammatic presentation of some pandemics in world history

\begin{tabular}{|c|c|c|c|c|}
\hline $\mathrm{S} / \mathrm{N}$ & $\begin{array}{l}\text { Name of } \\
\text { pandemic }\end{array}$ & Year & Place & Catastrophe \\
\hline 1 & $\begin{array}{l}\text { Infamous } \\
\text { "Black Death" }\end{array}$ & $\begin{array}{l}1347 \\
\text { and } \\
1351,\end{array}$ & $\begin{array}{l}\text { Started in } \\
\text { southwest } \\
\text { Asia and } \\
\text { reached } \\
\text { Europe }\end{array}$ & 75 million to 100 million people \\
\hline 2 & $\begin{array}{l}\text { Viral } \\
\text { hemorrhagic } \\
\text { fevers (VHF) }\end{array}$ & $\begin{array}{l}1545 \text { and } \\
1548\end{array}$ & Mexico & $\begin{array}{l}\text { estimated } 5 \text { million to } 15 \text { million of the native } \\
\text { population }\end{array}$ \\
\hline 3 & $\begin{array}{l}\text { Cholera } \\
\text { epidemic }\end{array}$ & $\begin{array}{l}1817- \\
1824\end{array}$ & $\begin{array}{l}\text { Asia and } \\
\text { Europe }\end{array}$ & 1,500 people \\
\hline 4 & Smallpox & $\begin{array}{l}1973, \\
\text { October } \\
\text { and } 1977\end{array}$ & Bangladesh & killing $30 \%$ of those infected. \\
\hline 5 & $\begin{array}{l}\text { Typhus } \\
\text { epidemics }\end{array}$ & $\begin{array}{l}1848, \\
1922\end{array}$ & $\begin{array}{l}\text { Yugoslavia, } \\
\text { Irish } \\
\text { immigrants } \\
\text { who had fled } \\
\text { to Canada to } \\
\text { escape the } \\
\text { Great Irish } \\
\text { Famine, } \\
\text { Russian Civil } \\
\text { War }\end{array}$ & 20,000 people-Three million people \\
\hline 6 & $\begin{array}{l}\text { Spanish flu or } \\
\text { influenza }\end{array}$ & $\begin{array}{l}1918- \\
1920\end{array}$ & $\begin{array}{l}\text { Soldiers } \\
\text { from Fort } \\
\text { Riley, } \\
\text { Kansas, ill } \\
\text { with Spanish } \\
\text { flu at a } \\
\text { hospital } \\
\text { ward at } \\
\text { Camp } \\
\text { Funston } \\
\end{array}$ & 50 million to 100 million people in just 18 months. \\
\hline 7 & $\begin{array}{l}\text { HIV-AIDS } \\
\text { epidemic }\end{array}$ & $\begin{array}{l}1981, \\
2014 \text { and } \\
2017 .\end{array}$ & $\begin{array}{l}\text { People } \\
\text { worldwide }\end{array}$ & $\begin{array}{l}\text { About } 35 \text { million people have died from AIDS - or } \\
\text { HIV-related illnesses }\end{array}$ \\
\hline 8 & $\begin{array}{l}\text { Severe acute } \\
\text { respiratory } \\
\text { syndrome } \\
\text { (SARS }\end{array}$ & $\begin{array}{l}2002- \\
2003\end{array}$ & $\begin{array}{l}\text { Asia and } \\
\text { Canada }\end{array}$ & $\begin{array}{l}\text { Spread to } 37 \text { countries globally within a matter of } \\
\text { weeks }\end{array}$ \\
\hline
\end{tabular}


TACKLING THE MENACE OF CORONA VIRUS PANDEMIC: EXPLORING ALTERNATIVE

STRATEGY OF SOCIAL RESPONSIBILITY INITIATIVE THROUGH SOCIAL STUDIES CURRICULUM

\begin{tabular}{|c|c|c|c|c|}
\hline 9 & Swine flu & $\begin{array}{l}1957 \text { and } \\
1958\end{array}$ & $\begin{array}{l}\text { Russia and } \\
\text { Hong Kong }\end{array}$ & flu killed approximately 2 million people \\
\hline 10 & $\begin{array}{l}\text { Ebola } \\
\text { outbreak }\end{array}$ & $\begin{array}{l}2013 \text { and } \\
2016\end{array}$ & $\begin{array}{l}\text { West Africa, } \\
\text { Liberia and } \\
\text { Sierra Leone. }\end{array}$ & 28,616 people \\
\hline 11 & COVID-19 & $\begin{array}{l}\text { January } \\
28, \quad 2020 \\
\text { till date }\end{array}$ & $\begin{array}{l}\text { The virus } \\
\text { appeared in } \\
\text { Wuhan, } \\
\text { China, in late } \\
2019 \text { and is } \\
\text { still } \\
\text { spreading to } \\
\text { people of the } \\
\text { whole world }\end{array}$ & $\begin{array}{l}\text { From } 28^{\text {th }} \text { January, } 2020-4^{\text {th }} \text { October, } 2021 \\
(4,819,138 \text { deaths cases were recorded }) \\
\text { https://www.worldometers.info/coronavirus/ }\end{array}$ \\
\hline
\end{tabular}

Sources: Huremović D. (2019). \& Janmejaya Samal, (2014).

\section{Index Case of Corona Virus in Nigeria}

The Federal Ministry of Health in Nigeria confirmed the first case of corona virus on the $27^{\text {th }}$ of February, 2020. It is reported that the first case surfaced in China in November, 2019, hence, the name COVID-19. The case in Nigeria was an Italian man, who returned from Milan, Italy to Lagos, Nigeria on $25^{\text {th }}$ February, 2020. He was confirmed positive at the virology laboratory of the Lagos University Teaching Hospital, part of the Laboratory Network of the Nigeria Centre for Disease Control. The patience was managed at the Infection Disease Hospital in Yaba, Lagos. The patient has been discharged after testing negative in Isolation Center. The disease has since spread to about 34 states in Nigeria, including the Federal Capital Territory, Abuja. There has been series of lockdown and it has affected the citizens and the economic activities of individuals and the governments have been badly affected. As at October 4th, 2021, Nigeria has recorded; 206, 076 confirm cases, 9, 256 active cases, 194, 097 discharge cases and 2, 723 number of deaths (covid19.ncdc.gov.ng).

At present, the COVID-19 epidemic has no known cure. Vaccines are being developed all over the world, but nations of the world are trying to treat the symptoms and developing vaccines to cure it. Many countries including Nigeria have imported the COVID-19 vaccines for the citizens. Campaigns are ongoing for the citizens to take the vaccines with the Political leaders taken the lead in Nigeria so as to encourage the citizenry that vaccine is safe. Effects are on all over the globe to contain the spread through physical or social distancing, Personal Protective Equipment (PPE), use of face mask, washing of hand frequently with hand sanitizers, maintain high level of hygiene etc. It is easier to contain the spread since there is no cure; hence, the collective social responsibility initiative is imperative to contain this contagious and dangerous dreaded epidemic that is killing human population like fowl all over the globe. 


\section{Efforts to Check the Spread of COVID-19 in Nigeria}

Several efforts at breaking the chains of COVID-19 epidemic are ongoing in Nigeria. The individual, NGOs, Religion institutions, government at all levels, corporate organization and PPP (Public Private Partnership). The Federal government through Task Force on COVID-19 is coordinating centrally. Their efforts are highlighted below:

1. Presidential briefing on COVID-19 guidelines.

2. Lockdown of people, activities and economy.

3. Enlightenment on the mode of transmission, symptom etc.

4. Lockdown of airspace and close of borders

5. Evacuating and burying of dead persons by COVID- 19

6. Testing of all the people who have travel history or have contact with those that tested positive

7. Procurement of testing kits, PPE, ventilators, ambulances and sanitizers.

8. Donations from foreign donors, individuals, corporate organizations, religion bodies, NGOs.

9. Construction of quarantine and isolation centres and hospitals for COVID-19 patients

10. Provision of palliatives to citizens, but was marred with irregularities due to lack of data of those that were actually poor.

11. Closure of schools, places of worships, markets, offices, banks, etc.

12. Legislation on wearing of mouth mask, washing of hands with sanitizers, social or physical distancing.

13. Ease of lockdown to prevent economic crisis at various levels.

14. Daily briefing by the Presidential Task force on COVID-19.

15. Spending huge among in the importation of covid-19 vaccines.

16. Vaccination of people starting from the Presidents and Political office holder publicly to the masses.

\subsection{Tackling the Menace of Corona Virus Pandemic by Exploring Alternative Strategy of Social Responsibility Initiative (ASSRI) through Social Studies Curriculum}

Danladi in Akinola (2013) opined that one of the goals of Social Studies curriculum is to produce citizens who are socially responsible. Akinola (2018) succinctly put it that social problem needs collective efforts to resolve it adequately. In the same dispensation, alternative strategy of social responsibility must involve collective mobilization of the political, social, economic, cultural and health institutions supported by individual groups and government.

FMWA and SW (2005) agreed that, the social responsibility involves the provisions of social needs that include; health, education, shelter, protection, nutrition, economic strengthening and psycho social. Every individual and social groups are significant in containing the COVID-19 epidemic through their ethical strategies and collective social responsibility initiative behavior. This is in line with supposition of Akinola (2018) that 
Social Responsibility Initiative (SRI) is a way of infusing systemic practice that create safe, caring and equitable schools so that all young people succeed in school and life, and help shape a safe, democratic and just society.

The alternative strategy of social responsibility initiative is expected to promote the participation of all and sundry in the efforts aimed at tackling Corona Virus pandemic in Nigeria. The stakeholders in the SRI will include Government, Institutions, schools, media, family, professionals, NGOs, health institutions. Every human being must be favorable disposed towards any genuine efforts to tackle corona virus pandemic, so that human life will be saved and environmental livable.

- Government: Government must as a matter of priority initiates policy that will provide favorable environment for the interplay of centripetal and centrifugal behavior of the stakeholders in collective social responsibility initiatives for tackling corona virus pandemic. Government has to coordinate other social initiations.

- Health Institutions: Health workers are the fulcrum of corona virus pandemic. They are at the heart and heat of the matter. They must be able to adopt protective behaviour and caring heart for others. The pandemic is very contagious and the health workers must protect themselves since even infected person may be healthy and care for asymptomatic and symptomatic patience. This will help us to break the chain of corona virus pandemic. They must be involved in having cure and develop vaccine for COVIC- 19 pandemic.

- Cooperate Organizations: They have great role to play. Tackling the dreaded pandemic is quite expensive. They can play their Social Responsibility functions by providing the Personal Protective Equipment (PPE), ambulance, sanitizer, soap, water, food, face masks, palliatives, test- kits etc.

- Individual: Every individual must obey the guidelines set by National Disease Control (NCDC), Government, Task force, international community and experts on how to protect self, protect others and stop the spread of Corona Pandemic. COVID-19 does not have leg to walk around, individual transport it from one place to the other. This makes individual attitudes pivotal in tackling the pandemic.

- Faith Based Organizations (FBO) Since all faith-based organizations pull crowd, they have to be involved in pragmatic efforts to tackle the spread of Corona virus pandemic. They have to adjust their programmes based on preventive measure to save lives. Their meeting schedules should follow the guidelines as spelt out by the authorities eg. physical distancing, nose and face mask, alcohol-based hand sanitizer, water, soap etc.

- Nongovernmental Organizations: They are expected to provide support for pandemic victims in kind and cash. They can be involved in the area of sharing palliatives, provision of test kits, preventive materials, ambulances and others that will break the circles of corona virus in the society. 
- Mass and Social media have the social responsibility of given genuine news, enlighten, educate and inform citizens about the dangers, mode of spread, symptoms, preventive measures etc. to the citizens.

- Curriculum offerings: Social Studies curriculum should be developed in such a way that it will tackle any social issues such as Corona Virus pandemic. The curriculum should be able to provide effective citizens who will be able to develop rational problem solving skills to handle problems as they arise in the society.

\section{Conclusion}

Behavioural change is imperative to tackling the dreaded corona virus pandemic that has no known vaccine and cure. All hands must be on deck. Everyone has a role to play in tackling the pandemic that has bedeviled the whole world.

\subsection{Recommendations}

Based on the position of this article it is recommended that:

- Everyone must be diligent in performing his/her role in curtailing the spread of COVID- 19 pandemic by saving themselves and others.

- Every citizen should obey the authorities by obeying the medical and non medical tips to curtail the spread of COVID 19 epidemic.

- Social Studies curriculum should be given its pride of place as a problem solving approach discipline in curtailing the spread of this dreaded COVID 19 pandemic through positive attitudinal change of citizens.

- Government through her agencies should be alive to her responsibilities to preserve lives of citizenry by providing favourable environment and relevant measures to tame the fearful COVID 19 virus

Figure 1: Interplay of roles if individuals in exploring Alternative Strategy of Social Responsibility Initiative (ASSRI) through Social Studies Curriculum

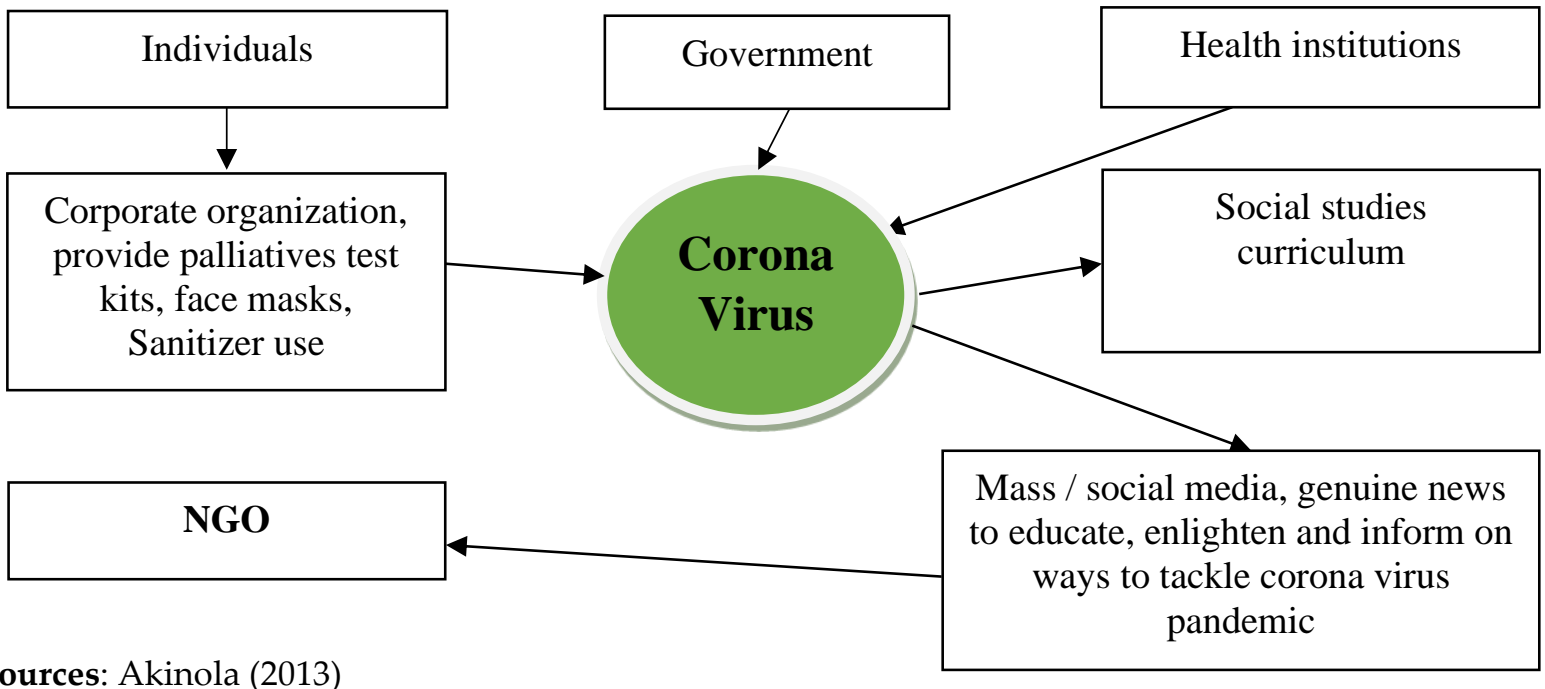

Sources: Akinola (2013) 


\section{Conflict of Interest Statement}

The author declares no conflicts of interests.

\section{About the Author}

David Babatunde Akinola, PhD Social Studies Education, Reader / Associate Professor of Social Studies Education. Department \& Institutional affiliation: Department of Educational Foundations, Faculty of Education, University of Abuja, P. M. B. 117, Abuja, Nigeria. Research Interests: Social Studies Education and Civic Education.

\section{References}

Adaralegbe, A. (1980). The Nigerian Social Studies programme: Retrospects and prospects. In NERDC Social Studies teaching issues and problems. Benin City: Ethiope Publishing Corporation.

Akinola, D. B. (2009). Implementation issues in Social Studies Education Curriculum in Nigeria: Problems and Prospects Approaches in International Journal of Research Development1 (2)213-223

Akinola, D. B. (1998). Gender and Students' Achievement in Social Studies in Obafemi Awolowo University Ile-Ife, An Unpublished Project submitted to Faculty of Education, O.A.U. Ife.

Akinola, D. B. (2013). Terrorism Education in Nigeria: Exploring alternative strategy of social responsibility initiative through the school curriculum. Nigerian journal of social studies and civic education 5(1) 72-83

Akinola, D. B. (2014). The substance of social studies education for colleges and universities in Nigeria. Abuja: Chartered Graphics Press.

Akinola, D. B. (2018). Principles and practice of Social Studies Education for Tertiary institutions in Nigeria. Abuja: Chartered Graphics Press.

Ashby, R. W. (1964) Introduction to Cybernetics. London: Routledge Kegan \& Paul.

von Bertalanffy, L. (1968). General System Theory: Foundations, Development, Applications. New York: George Braziller.

Danladi, E. N. (2008). Alleviating Poverty in Nigeria. The role of Social Studies Education (A workshop paper presented at FCT-COE, Zuba)

Federal Ministry of Women Affairs and Social Welfare (2005) Child's Right Acts. Abuja: Marvelous Ventures

Food and Agricultural Organization (1995). Action on Universal Food Security Committee on World Food Security: Rome.

Gleditsch, P. (2001). Environmental Change, Security and Conflict in Crocker, C. A. Hampson, F. O. and Aall (eds) Turbulent Peace: The challenge of Managing International Conflict. Washington D.C.: US Institute of peace. 
Huremović D. (2019). Brief History of Pandemics (Pandemics Throughout History. Psychiatry of Pandemics: A Mental Health Response to Infection Outbreak, 735. https://doi.org/10.1007/978-3-030-15346-5 2

Iyiola, O. (1988). Introduction to Psychological Foundations of Education for Education Undergraduates Ibadan: Bezekos Printing Press

Janmejaya Samal (2014). A Historical Exploration of Pandemics of Some Selected Diseases in the World International Journal of Health Sciences \& Research (www.ijhsr.org) 4 (2)1-6

Martins, S. P. (2009). Food and Nutrition Security in Niger, Research Institute Report, Yenagoa: Ministry of Agriculture.

Mayo Foundation for Medical Education and Research MFMER 1998-2020 majorclinic.org

Mohammad, R. J. (2004). Contemporary Public Issues in Ololobou Y.P.S. Social Studies for Citizenship Education Pankshin: Academic Trust Fund

Muhammad Adnan Shereen, Suliman Khan, Abeer Kazmi, Nadia Bashir, Rabeea Siddique (2020) Origin, transmission, and characteristics of human coronaviruses Journal of Advanced Research 24 (2020) 91-98 www.elsevier.com/locate/jare

National Agenda on Food (1993). Food Security and Nigerian Agriculture. Abuja: Federal Ministry of Agriculture.

NCDC Coronavirus COVID-19 Microsite (covid19.ncdc.gov.ng)

Obodumu, J. O. (2006). Information Technology and Food Security in Nigeria Benue State University Journal of Education 7(195-200)

Ogoh, A. P. (2008). The Place of Social Studies in Enhancing National Security in Nigeria in Nigerian Journal of Social Studies xi (1) 28-37

World Bank (1991). Nigeria Strategy for Food and Nutrition Security- World Bank Document No 9040 UN 
Author(s) will retain the copyright of their published articles agreeing that a Creative Commons Attribution 4.0 International License (CC BY 4.0) terms will be applied to their work. Under the terms of this license, no permission is required from the author(s) or publisher for members of the community to copy, distribute, transmit or adapt the article content, providing a proper, prominent and unambiguous attribution to the authors in a manner that makes clear that the materials are being reused under permission of a Creative Commons License. Views, opinions and conclusions expressed in this research article are views, opinions and conclusions of the author(s). Open Access Publishing Group and European Journal of Education Studies shall not be responsible or answerable for any loss, damage or liability caused in relation to/arising out of conflicts of interest, copyright violations and inappropriate or inaccurate use of any kind content related or integrated into the research work. All the published works are meeting the Open Access Publishing requirements and can be freely accessed, shared, modified, distributed and used in educational, commercial and non-commercial purposes under a Creative Commons Attribution 4.0 International License (CC BY 4.0). 